\title{
Declaration of Statehood by Somaliland and the Effects of Non-Recognition under International Law
}

\author{
Temesgen Sisay Beyene* \\ Department of Law, School of Law, Bahir Dar University, Bahir Dar, Ethiopia \\ Email: temesgen.sisay@yahoo.com
}

How to cite this paper: Beyene, T. S. (2019). Declaration of Statehood by Somaliland and the Effects of Non-Recognition under International Law. Beijing Law Review, 10, 196-211.

https://doi.org/10.4236/blr.2019.101012

Received: January 27, 2019

Accepted: March 15, 2019

Published: March 18, 2019

Copyright () 2019 by author(s) and Scientific Research Publishing Inc. This work is licensed under the Creative Commons Attribution International License (CC BY 4.0).

http://creativecommons.org/licenses/by/4.0/

Open Access

\begin{abstract}
After the downfall of the Socialist and military Siad Barre regime in Somalia, Somaliland took an immediate action of independent declaration of statehood from its failed "parental state", Somalia. It has been almost twenty five years since Somaliland declared its independence, established its own government, kept the peace, and managed to flourish in a kind of stability. Nevertheless, the international community has not recognized its act. Among the former Somali Republic territories, it is now only Somaliland that secured democratic and stable government and sustainable peace in the region. Somalia, which was part and "heir" of the former Somali Republic, is now unstable and even challenged by the Islamist extremist group, Al-Shabab. Somaliland, once under the colonial power of the British Empire like other African countries, argues it should be recognized as an independent state. This article investigates the legal understandings of statehood, from the Montevideo Convention to the more recent emphasis on self-determination, and then turns to the case of Somaliland, arguing that Somaliland deserves statehood status and other states should recognize it as a state as there is no legal ground under international law that justifies an otherwise position.
\end{abstract}

\section{Keywords}

Somalia, Somaliland, Statehood, Independence, Self-Determination, Montevideo Convention

\section{Introduction}

Somaliland is located in the conflict and war prone area of the Horn of Africa.

${ }^{\star}$ Temesgen Sisay is an Assistant Professor in comparative constitutional law at Bahir Dar University School of Law. 
The region has experienced various political turmoil since the beginning of the 1990s and the majority of countries of this region have experienced coup d état. Following the scramble for Africa, this region, except Ethiopia that has successfully defeated Italy at the battle of $A d w a^{2}$, was under the colonial control of European powers.

The experience of colonialism at the hands of former colonial rulers, Britain and Italy, and the political instability that marked their departure, shape the main causes of Somalia's current turmoil. After the end of the northern Somalia (British Somaliland) and the Southern Somalia (Italian Somali) rule, the state of Somalia came to existence in 1960 by merging the two independent northern and southern part of Somalia. After some years of civilian rule, the military regime of Siad Barre overthrow (Clarke \& Geosende, 2003) the civilian government and since then the Somali National Movement (SNM) started its struggle till Somaliland declared its independence in 1991. Though Somaliland declared its independence before twenty five years, its statehood is not formally recognized by the international community including the United Nation (UN) and African Union (AU). Having unrecognized status of statehood, it is only Somaliland that has most stable and democratic government compared to other former "Somali Republic" territories. The al-Qaeda affiliated Al-Shabab ${ }^{3}$ controlled and became a threat to other Somalia territories except Somaliland.

This article explores the legality of Somaliland's assertion of independence from the perspective of international law and argues for the recognition of Somaliland as an independent state. It discusses the legitimacy of such independence in a historical and decolonization lens, considering the nature of sovereign rights over Somaliland. Moreover, it explores the case of recognition of Somaliland by other member states of the United Nation from the current international law point of view, specifically the Montevideo Convention. The article asserts that Somaliland should be recognized as an independent nation and other states should also recognize it as an independent state as it fulfills the requirement under the Montevideo Convention.

\footnotetext{
${ }^{1}$ In January, 1991, Siad Barre's 21 year old regime was overthrown in Somalia, which led to the declaration of independence by the northern half, the Republic of Somaliland in May 1991. In June 1991, Colonel Mengistu Haile Mariam was overthrown in Ethiopia after 17 years bloody civil war, that has ended with the secession of Eritrea and the loss of Ethiopia to its only see out-lets. In Sudan, secessionist movements were organized in different parts of the country where the Southern Sudan People's Liberation Army got the upper hand and Sudan is divided in to Northern and Southern Sudan.

${ }^{2}$ The Battle of $A d w a$, in which Ethiopian forces, united under Emperor Menelik II, defeated an invading force of Italian troops, was one of the most significant turning points in the history of modern Africa. It occurred, in 1896, when the "colonial era" was well advanced on the African continent, and it served notice that Africa was not just there "for the taking" by European powers. More than this, it marked the entry of Ethiopia into the modern community of nations: Menelik's victory over the Italians caused the other major European states, and Italy itself, to recognize Ethiopia as a sovereign, independent state in the context of modern state craft.

${ }^{3} A l$ Shabaab (Arabic for "the youth") is an Islamic militant group that aims to create an Islamic state in Somalia. Al Shabaab is linked to Al Qaeda both ideologically and through leadership contacts, training and joint operations in the Horn of Africa.
} 


\section{Facts to Be Known about Somaliland}

The northern part of Somalia was known as the Protectorate under the British rule from 1884 until June $26^{\text {th }}, 1960$ when Somaliland got its independence from Britain. Before signing a friendship treaty with Britain, the northern part of Somalia was an independent state. There were different reasons that triggered the clans who were living in the northern part of Somalia to sign a treaty with Britain. The main reason that triggered the northern part of Somalia to sign a treaty with Britain was mainly related with their fear against the expansionist movement of the Ethiopian Empire in the region ${ }^{4}$. Instigated by this reason, Ise, Gadabursi, Habar Garhajis, Habar Awal, and Habal Tol Jalo clans signed formal treaties with Great Britain by the end of 1884 (Anthony \& Carroll, 1993). This treaty had no clauses related to cession and it only gave to Britain the right to pre-emption (Anthony \& Carroll, 1993). This friendship treaty was properly designed to maintain the independence of different clans who were living in the northern Somalia and large measure of sovereignty was enjoyed by the clans (Anthony \& Carroll, 1993).

After sixty six years of control by the British Empire, Somaliland got its independence on June 26, 1960 and the new state received recognition from thirty five countries including all five permanent members of the Security Council. But, the independence of Somaliland stayed only for five days. Five days later, the newly established Somaliland and the Italian Somali agreed to form a union through a bilateral treaty, though the treaty ended up with irregularities and finally Somaliland left the treaty. Both states drafted a separate treaties and Somaliland sent its treaty to the authorities in Mogadishu. Yet authorities in Mogadishu did not send their own treaty to the authorities in Barbara. The draft treaty sent by the Somaliland authorities was never approved by the Southern Somali authorities and rather they drafted their own, the Act of Union, and approved by the national legislature (Paolo, 1969). In the process, the authorities in Somaliland were never consulted and did not give their consent for the newly approved Act of Union.

In July $1^{\text {st }}, 1960$ the Somali Republic was formed by uniting the British Somaliland and the Italian Somali. Though they formed the Republic by joining the British and the Italian Somali territories, the union did not last for a longer period of time peacefully. The failure to fulfill the aspirations of the people of northern Somalia, led the Republic to a civil war from 1980s onwards and eventually to the collapse of the Somali Republic (Peter, 2011). Immediately after the collapse of the Somali Republic, the people of Somaliland held a congress in which it was decided to withdraw from the "Union" with Somalia and to reinstate Somaliland's sovereignty and declared their independence. Though Somaliland declared its independence twenty five years ago, its statehood is not recognized by the international community. Moreover, since the declaration of the ${ }^{4}$ FOREIGN AREA STUDIES, The American University, SOMALIA: A COUNTRY STUDY 1-61 (Harold D. Nelson ed., 1982). 
independent statehood of Somaliland, the country is not yet recognized by any international and regional institutions like United Nations (UN) and African Union (AU).

\section{The Right to Self-Determination of the People of Somaliland}

\subsection{Conceptual Underpinnings on the Right to Self-Determination}

The primary emergence of the principle of self-determination was materialized after the First World War (Shaw, 2003). It is possible to say that; self-determination was "the benchmark for peacemakers at Versailles". The President of United States of America Woodrow Wilson described the national self-determination as "an imperative principle of action" (Henry \& Philip, 2000). The right to self-determination in the context of International Law is the right of the people ${ }^{5}$ to determine their own fate. Unless the inhabitants of a certain territory are recognized as people, they are not entitled to enjoy their right to self-determination. In particular, the principle allows the people to choose their own political status and to determine their own form of economic, cultural and social development (Malcolm, 1986). The right to self-determination can be exercised in a variety of different outcomes ranging from political independence through to full integration within a state. The importance lies in the right of choice, so that the outcome of a people's choice should not affect the existence of the right to make a choice.

The principle of the right to self-determination is significantly included in Article I of the UN Charter. Before the issue was included under the UN Charter, it was explicitly embraced by the former US President Woodrow Wilson, Lenin and others, and became the guiding principle for the reconstruction of Europe following $\mathrm{WWI}^{6}$. Moreover, the principle of self-determination of peoples has been subject to a conceptual evolution which began in post-Second World War era and accelerated in 1960's due to the decolonization process. This evolution pertains to the transformation of self-determination which was firstly conceived as a political principal to a peremptory legal norm, i.e. jus cogens. Self-determination has many characteristics formulated on different legal platforms. However, the International Covenant on Civil and Political Rights (hereinafter referred to as "ICCPR") and the International Covenant of Economic, Social and Civil Rights (hereinafter referred to as "ICESCR") constitute perhaps the most crucial phase in the evolution of this right. The implementation of self-determination has always been more controversial than its content which has been laid down by the Covenants. In addition, the concept is also included in other international as well as regional human rights and other treaties and also in the decisions of the ${ }^{5}$ U. N. Charter art. 1, para. 2; International Covenant on Civil and Political Rights art. 1, Dec. 16 1966.

'http://www.unpo.org/article/4957 last accessed on September 27, 2016. 
International Court of Justice in different cases ${ }^{7}$.

\subsection{The Right to Self-Determination in the Context of the Inhabitants of Somaliland}

The inhabitants of Somaliland have the right to self-determination under international law. There are different legal grounds that justify the right to self-determination and independent declaration of statehood of Somaliland under international law from three different perspectives.

\subsubsection{The Right to Self-Determination Is People's Right}

First, I argue that the inhabitants of Somaliland have the right to self-determination as they are considered to be a people under international law. In understanding the word what "people" mean, there are objective and subjective criteria. From the point of view of objective criteria "people" is defined from the context of having their own distinct language, ethnicity and religion (Markus, 2006) from the rest of the inhabitants living in a certain area. When we literally evaluate the case of the inhabitants of Somaliland from this objective criteria point of view, they may not deserve the status of "people." Because, they speak Somali language, are ethnically Somali, and practice Sunni Islam as do almost all Somalis. But, this standard is overly broad and even doesn't consider some practical cases in most of European and African countries. In Europe for instance, Norwegians, Swedes, and Danes are considered different "peoples" despite their shared language, ethnicity, and religion (Lars, 2000). Moreover in Africa, Swahili serves as a national or official language of four African nations: Tanzania, Kenya, Uganda and the Democratic Republic of the Congo though they are considered as different "people" (Lambert, 1995). The mere fact that the inhabitants of Somaliland are speaking the same language with the rest of Somalis, follow Sunni Islam and are ethnically Somali does not affect their status of being considered as people. As Somalilanders, they have their own identity, culture and they do consider themselves as Somalilanders not as the rest of Somalis.

When we see the subjective criteria, it is totally different from the objective one. To determine whether the inhabitants or groups of a certain territory to deserve what "people" mean, it only focuses on the perception of the inhabitants or the groups themselves as if they are a distinct people and existed there (Jean, 1948). This standard gives a room for the inhabitants of certain area themselves in what context and what sense they identify themselves. As long as the inhabitants perceive themselves in a certain way, it is only their own business.

In addition to the self perception of the inhabitants themselves, the understanding of others towards the inhabitants has its own effect. Totally, the propo-

${ }^{7}$ See for example, the right to self determination is included in the Declaration of Principles of International Law Concerning Friendly Relations and Co-operation Among States adopted by the UN General Assembly in 1970, the Helsinki Final Act adopted by the Conference on Security and Co-operation in Europe (CSCE) in 1975, the African Charter on Human and Peoples' Rights of 1981, the CSCE Charter of Paris for a New Europe adopted in 1990, and the Vienna Declaration and Program of Action of 1993. The principle has been also affirmed by the ICJ in the Namibia case, the Western Sahara case, and the East Timor cases. 
nents of subjective criteria argue that group recognition may exist because the group perceives itself as existing and different, or because outsiders define the group as different from them, or some mixture of internal and external identification. Sartre, for example, argues that "the Jew is a man that other men consider to be Jewish... it is the anti-Semite that makes the Jew" (Jean, 1948). That means anti-Semite attitude of others has contributed a lot for the recognition of Jew people. As long as the group identify themselves as a distinct and other groups consider them different, they should be considered as "people" based on the subjective criteria.

The inhabitants of Somaliland, ethnic Somalis tremendously of the Isaaq clan, were singled out by the past administration for persecution because of their clan affiliation (Jean, 1948). By committing murder against a segment of its own people, and by defining that section with an immutable and collective characteristic like clan affiliation, the state may have raised the Isaaq to the status of a "people" with rights of self-determination independent of the "greater Somali" community. The inhabitants of Somaliland have built the identity of Somalilander from common colonial history ${ }^{8}$ and their struggle against Siad Barre regime in their process of nation building since 1991. Based on the above arguments, I strongly argue that, the inhabitants of Somaliland deserve and fulfill the status of "people." As long as the inhabitants of Somaliland deserve the status of people, they are entitled to enjoy their right to self-determination as the other people who are enjoying the same right.

\subsubsection{Instance of Decolonization Justifies Somaliland's Right to Self-Determination}

The second ground that helps with establishing Somaliland's right to self-determination is the instance of decolonization'. Though political scientists and lawyers who are working in the area of self-domination are in agreement that the right to self-determination ensures colonized peoples may form states independent of their colonial rulers, the idea seems somewhat unclear concerning "secession" ${ }^{10 "}$ from post-colonial states. The Declaration on the Granting of ${ }^{8}$ In 1888, after signing successive treaties with the then ruling Somali Sultans such as Mohamoud Ali Shire of the Warsangali Sultanate, the British established a protectorate in the region referred to as British Somaliland. The British garrisoned the protectorate from Aden and administered it from their British India colony until 1898. British Somaliland was then administered by the Foreign Office until 1905 and afterwards by the Colonial Office. Generally, the British did not have much interest in the resource-barren region. The stated purposes of the establishment of the protectorate were to "secure a supply market; check the traffic in slaves, and to exclude the interference of foreign powers". The British principally viewed the protectorate as a source for supplies of meat for their British Indian outpost in Aden through the maintenance of order in the coastal areas and protection of the caravan routes from the interior. Hence, the region's nickname of “Aden's butcher's shop" (Lacey, Marc (5 June 2006). “The Signs Say Somaliland, but the World Says Somalia”. New York Times. Retrieved 2 February 2010).

${ }^{9}$ The charter of the Organization of African Unity government thus contains an agreement by the signatory governments to "respect the frontiers [of all member states] existing on their achievement of national independence."

${ }^{10}$ In fact the writer of this article does not agree that Somaliland is seceding from the Republic of Somalia Rather, it is claiming its right of self-determination based on the principle of decolonization from the previous colonizer. 
Independence to Colonial Countries and Peoples is predicated on the principle of self-determination for the justification of decolonization. The use of colonial boundaries to form independent states was a principle supported by the Organization of African Unity, known today as the African Union. The then African Union continues to maintain the position that its member states respect the borders with which they achieved independence and in fact this principle works for Somaliland.

The current Somaliland was under the colony of the British Empire and it was known as British Somaliland. In colonial administration, the northern part of Somalia, now Somaliland was separately administered with the Southern part Somalia. Like other African people ${ }^{11}$, the people of Somaliland got their independence from Britain in 1960. When Somaliland was freed from British colonial rule and declared its independence, it was recognized by different countries including members of the Security Council. Northern Somalia, Somaliland was the first Somali territory that got its independence and that was recognized by the UN. The Southern Somalia, now the Somali Republic and Punt land got their independence after Somaliland. Though Somaliland declared its independence and got recognition by the UN as an independent state, its independence did not last long. The statehood of Somaliland stayed only for five days and later it agreed to join with the northern Somalia and establish the Somali Republic ${ }^{12}$.

Five days later, the newly established Somaliland and the Italian Somali agreed to form a union through a bilateral treaty, though the treaty ended up with irregularities. These irregularities happened due to the act of authorities who were in Southern Somalia. Both states drafted separate treaties and Somaliland sent its treaty to the authorities in Southern Somalia. Yet authorities in Sothern Somalia did not send their own treaty to the authorities in Somaliland. The draft treaty sent by the Somaliland authorities was never approved by the Southern Somali authorities and rather they drafted their own, the Act of Union, and approved by the national legislature (Paolo, 1969). When all the process happened, the authorities in Somaliland were never consulted and did not give their consent for the newly approved Act of Union.

In July $1^{\text {st }}, 1960$ the Somali Republic was created by uniting the British Somaliland and the Italian Somali. The union created in this way did not get the consent of the people of Somaliland and in-fact violates the law of treaty under International Law. It is true that, initially the people of Somaliland consented to join the Southern Somalia and form the Somali Republic. But the procedure that has been undergone to establish the republic was wrong and against the consent of the people of Somaliland. The Vienna convention on the law of treaty clearly indicates that, a treaty should get the consent of the other state to have a valid status $^{13}$. The bilateral treaties drafted by Northern Somalia and Southern Somalia

\footnotetext{
${ }^{11} 1960$ s is considered as African year. This nomenclature is given as the majority of African countries were liberated from the colonial rule during this time.

${ }^{12}$ Somalilandgov.com, available at http://www.somalilandgov.com (last visited September 27, 2016.); see also Somaliland.Org, available at http://www.somaliland.org (last visited Dec. 20, 2012).

${ }^{13}$ Vienna Convention on the Law of Treaties, 1969, Article 24.2.
} 
to form the Republic were invalid because they never received consent from the opposite side. The Vienna Convention stipulates that states must express their consent to be bound by a treaty for the treaty to enter into force ${ }^{14}$. The treaty drafted by Somaliland, the Law of Union between Somaliland and Somalia (Law of Union), was to enter into force after being signed by the "duly authorized representatives of the peoples of Somaliland and Somalia"15. Although the representatives from Somaliland signed the treaty, the representatives from Southern Somalia did not. Instead, the Legislative Assembly of the Somalia Trust Territory (Italian Somalia) approved "in principle" a different treaty, the Atto di Unioni (Act of Union) ${ }^{16}$. The Act of Union differed substantially from the treaty drafted by Somaliland. The provisional President of the Republic, a southerner, then issued a presidential decree formalizing the Union of the two states. Six months later, the Atto di Unioni was approved by the National Assembly. As formal agreements between two states, both treaties of unification therefore appear to lack the consent of the other party to the agreement.

Though we assume that the Act of Union did form a legitimate treaty, however, Somaliland could reasonably argue in another way that material breaches of the treaty under the dictatorship allow the north to terminate the agreement ${ }^{17}$. Accordingly, the new Somali state formed within a constitutional framework through the Law of the Union and the Act of the Union did not get the blessing of the northerners. Though the Union was formed and declared in whatever way, it did not last for long period of time. The constitutional order was overthrown and military dictatorship controlled all political powers in Somali Republic in 1969 (Roethke). However the military dictator that breached the treaty was not a party to the treaty and non civilian leader, Somaliland still maintains its right to terminate the agreement. The Prerequisites that instigated Somaliland to join with the Southern Somalia no longer existed and Somaliland can claim termination of the treaty as the very objective of the treaty was not to install a military dictatorship. The treaties signed by the Italian and the British Somaliland to form the Union were invalid. As long as the treaties were invalid and terminated due to the act of the Southern Somali groups, Somaliland's claims to independence would not violate international law and territorial integrity of a "united Somalia", since that union has ceased to exist. Somaliland's unilateral declaration of statehood and decision to secede from the Union is justified as a "legitimate exercise of self-determination under the decolonization framework of the Declaration on the Granting of Independence to Colonial Countries and Peoples"18.

Considering the violation of the bilateral treaty by the Southern Somali and invalidating those treaties, the secession or withdrawal of Somaliland from the ${ }^{14}$ Ibid.

15"Somaliland and Somalia: The 1960 Act of Union-An Early Lesson for Somaliland." ${ }^{16} \mathrm{Ibid}$.

${ }^{17}$ Article 60 (1) of the Vienna Convention allows parties to bilateral treaties to invoke breach as grounds for termination.

${ }^{18} \mathrm{Ibid}$. 
Union or the Somali Republic doesn't amount dismember a sovereign state, rather it is a restoration of a previously independent and sovereign state to its former status. That means, Somaliland still retain the right to secede as the reason that the Act of Union was invalid under the law of treaty.

\subsubsection{Grave Human Rights Violation during Barre's Regime}

The other legal ground that justifies the unilateral statehood declaration of Somaliland is occurrence of grave human rights violation against its inhabitants during siad Barre's regime. The occurrence of this human rights violation justifies the right to declare their independence. As it is explained by Hugo Grotius, a well known international law jurist, the existence of human rights violation justifies rebellion and "the people can depose a ruler who openly shows him to be the enemy of the whole people because a ruler cannot simultaneously exercise both the wills to govern and to destroy" (Kelsey, 1925). Moreover, P. Nanda argues that, if the fundamental rights and freedoms of the people are affected in a genocidal scale, the people have the right to claim their right to self determination through secession (Nanda, 1981). This argument will consolidate properly my premises which says, the violation of people's right is an adequate mechanism to declare once self-determination. When the violation of the right is manifested in a greater degree, genocidal scale, the people are entitled to enjoy their right to self determination under international law.

Among the various international human rights instruments, the Preamble to the Universal Declaration of Human Rights recognizes the right to rebel against a government which is guilty of grave violations of human rights ${ }^{19}$. Since the people have the right to be protected against the violation of their right, the mere violation of the right will call the question of the right to self-determination to be free from this violation. This grave violation of human rights is well documented in the history of the people of Somaliland. During the regime of Siad Barre, thousands of people from Somaliland were killed, imprisoned, and their property was looted ${ }^{20}$. There was also a targeted attack against the wealthier clan members of Isaq in Somaliland and this genocidal attack was done through the help of former German Democratic Republic and KGB (Omaar, 1992). The genocidal attack on the Isaq clan was intensified with the military bombing and shelling of the northern cities, Hargeisa and Burao. Due to this genocidal attack, around fifty thousand people were killed in Somaliland and around five hundred thousand people were fled to the neighboring Ethiopia from Somaliland ${ }^{21}$.

The occurrence of such genocidal scale human rights violation against the

\footnotetext{
${ }^{19}$ See for example UN. General Assembly. Res. 217 A (I), U.N. Doc. A/810, at 71 (1948) which says "whereas it is essential, if man is not to be compelled to have recourse, as a last resort, to rebellion against tyranny and oppression, that human rights should be protected by the rule of law..."; moreover, see also LUIS KUTNER, DUE PROCESS OF REBELLION (1974) (positing that human rights need to be legally protected, otherwise rebellion is forced upon the people).

${ }^{20}$ Somali Army Killed up to 60,000 Civilians in North, Reports Says, Reuters, Jan. 18, 1990, available in LEXIS, Nexis Library, Reuters File.

${ }^{21}$ See US DEPARTMENT OF STATE DISPATCH, 1990 Human Rights Report: Somalia (Feb. 1, 1991) (describing the human rights atrocities in Somalia).
} 
people of Somaliland was the main reason that obliged them to declare their independence in 1991. Since they have an inherent right to be protected from such kind of grave violation of human rights, they declared their independence unilaterally.

\subsubsection{Inability to Exercise Internal Self-Determination Right}

Lastly, in addition to gross violation of human rights committed against the people of Somaliland during Siad Barre's regime, they were also denied to exercise their internal right to self-determination. When there is a violation of an internal self-determination, people will be obliged to rebel against the regime to declare their own external self-determination for the sake of achieving the internal one. As Anthony J. and Rajagopal have rightly explained it, "the denial of a people's internal self-determination' leads to the revival of their external right of self-determination." That is what clearly happened in Somaliland. The violation of their internal self-determination when they were part of the Somali Republic has instigated them to search another alternative and to declare their external self-determination.

Moreover, in addition to the violation of their internal self-determination during their membership of the Somali Republic, a political vacuum was created when the Republic was disintegrated. When the Republic was disintegrated, the people of Somaliland had no any other alternative than declaring their external self determination and proclaiming their independence as a nation state. Then, I argue that Somaliland still entitled to enjoy its right to self-determination and secede from the Republic of Somalia as it was not able to exercise its internal right to self-determination while it was under the Union and the solution provided under international law in such circumstance is secession which Somaliland properly did.

\subsection{State Recognition under International Law Regime}

In this section of the article, the issue of whether other states should recognize Somaliland as an independent state or not will be addressed. Moreover, I will evaluate the effect of the recognition or the non-recognition by other States on the Statehood of Somaliland in the context of International Law. In the current understanding and discourse of international law regime, there are two different views that deal with the issue of state recognition.

\subsubsection{Constitutive Theory}

The first theory that deals with the issue of state recognition is constitutive theory. According to this theory, a new state gets its recognition if and only if it is recognized by the already established states and recognition is mandatory (Lauterpachet, 1947). When we apply this principle to the current understandings of international law regime, a "state" has to be recognized by the member states of the United Nation in order to have a status of international legal personality. If there is no recognition from the member countries of the UN, a new 
"state" will not have legal personality under international law. This theory is full of criticism. The main criticism is related to the non-recognized state's obligation and the theory seems to conclude that, prior to recognition there is no obligation. But, this assertion does not work and non recognized states are also entitled to enter in to legal obligation. For example, the unrecognized state Somaliland has signed a treaty with Ethiopia for the use of its port of Berbera (Alison, 2007).

\subsubsection{Declaratory Theory}

The second theory concerning a state recognition is declaratory theory. According to this theory, a state will be recognized and have a legal personality under international law immediately when it fulfills the requirement of statehood under international law and recognition can serve no legal significance than political purpose. The advocates of this theory further argue that, when a state fulfils the requirement of statehood, it immediately establishes an obligation on other states to recognize the new state. Even though the proponents of this theory argue in this way, the current state practice does not show this reality.

Based on the above two theories, it is possible to reach a conclusion that, state recognition is discretionary and it does not have any legal purpose under international law. If sate recognition is discretionary and outside the scope of the law, dealing either with declaratory or constitutive theory lacks any utility (Ian, 1979).

\subsection{The Requirements for Statehood under International Law}

The question now is whether Somaliland fulfils the requirement of the state under international law or not. The criteria to fulfill statehood are provided under the Montevideo Convention. The Montevideo Convention lists four basic elements required for statehood; a permanent population, a defined territory, government, and a capacity to enter into relations with other states ${ }^{22}$. The Montevideo Convention in addition indicates that although the political existence of the state is independent of recognition by the other states, such recognition may be explicit or tacit ${ }^{23}$. Different Countries have been applying the convention differently in different times according to their own political as well as diplomatic interests. But, United States of America has been consistent in its understanding and application of the Montevideo Convention ${ }^{24}$. This has been witnessed in the case of Kadic v. Karadzic and the self proclaimed Bosnia-Serb Republic within Bosnia-Herzegovina, referred as Sprska named as a state and its leaders were held as accountable for the misdeeds they have committed against the civilians ${ }^{25}$. The court summarized its conclusion that Srpska met the definition of a state by noting that it is supposed to control defined territory, manage its populations within its power, and to have entered into agreements with other governments. It has a legislative, executive and, a judiciary branches, and its own currency. These conditions readily appear to convince the criteria for a state in all respects ${ }^{22}$ The Montevideo Convention on Rights and Duties of States art. 1, Dec. 26, 1933.

${ }^{23}$ Ibid, arts. $3 \& 7$.

${ }^{24}$ See, e.g., Klinghoffer v. S.N.C. Achille Lauro, 937 F.2d 44, 47 (2d Cir. 1991); Nat'l Petrochemical Co. v. M/T Stolt Sheaf, 860 F.2d 551, 553 (2d Cir. 1988).

${ }^{25}$ Kadic v. Karadzic, 70 F.3d 232, 236-37 (2d Cir. 1995). 
of international law. Moreover, the US Department of State also strengthening its position and made a press conference that;

In judging whether to recognize an entity as a state, the United States has traditionally looked to the establishment of certain facts. These facts include effective control over a clearly defined territory and population; an organized governmental administration of that territory; and a capacity to act effectively to conduct foreign relations and to fulfill international obligations ${ }^{26}$.

Whatever the consistent or different positions of various countries in the issue of state recognition, the political existence of a state is not influenced by the recognition or non recognition of other states. This position has been upheld by the Montevideo Convention and provided that.

The political existence of the state is independent of recognition by the other states. Even before recognition the state has the right to defend its integrity and independence, to provide for its conservation and prosperity, and consequently to organize itself as it sees fit, to legislate upon its interests, administer its services, and to define the jurisdiction and competence of its courts ${ }^{27}$.

The essence of the above provision is that, the political existence of the state is independent of recognition by the other states and such recognition may be made either explicitly or tacitly. As long as a certain entity fulfils the four Montevideo standards on population, territory, government and sovereignty, the recognition or non-recognition by other countries has no significant position in international law. Recognition only serves to prove that the new state is capable of entering into relations with other states. It has to be also noticed that, recognition is a political act that depends on the discretion of the recognizing state.

\subsection{Does Somaliland Fulfill the Montevideo Convention and Qualify as a State?}

The Montevideo Standards are fulfilled by Somaliland though the international community frustrates to accept this real and biter truth. Somaliland declared its unilateral independence due to the absence of an effective parental state that could bless or curse its act. When Somaliland declared its independence, its "parental state", Somalia was without effective government and under bloody civil war. Even now, Somaliland's so called "parental state" is being threatened by the Islamist extremist and self-declared al-Qaeda affiliate, $A l-S h a b a b^{28}$. In Somalia, ${ }^{26}$ United States Department of State Press Relations Office Notice, Nov. 1, 1976, quoted in Eleanor C. McDowell, Contemporary Practice of the United States Relating to International Law, 71 AM. J. INT'L L. 337 (1977).

${ }^{27}$ Montevideo Convention, Art.3.

${ }^{28}$ In a February 2010 press conference, Al Shabaab declared it was aligned with Al Qaeda "to confront the international crusaders and their aggression against the Muslim people." In order to do so, an Al Shabaab leader said, "the jihad of the Horn of Africa must be combined with international jihad led by the Al Qaeda network headed by Sheikh Osama bin Laden." In June 2011, Al Shabaab consolidated its affiliation to Al Qaeda by swearing allegiance to Ayman al Zawahiri, who assumed leadership of Al Qaeda after bin Laden's death in May 2011. A joint communiqué issued by Al Shabaab and Al Qaeda in February 2012 further solidified the relationship between the two groups. Zawahiri welcomed "the joining of the Al Shabaab Al Muhajideen Movement in Somalia to Al Qaeda in support of the jihad gathering in the face of the Zionist Crusade campaign." 
there is no effective government that could defend itself from Al-Shabab and other clan based conflicts. Rather, the transitional government is there only with the help of combined African Union (AU) Mission to Somalia (AMISOM) ${ }^{29}$. The transitional government could not survive in the territory without the help of foreign powers. In fact, Al-Shabab is not the only problem of Somalia and its transitional government. Rather, clan based competition and rivalries are also reasons that weaken Somalia and its army not to defend $A l-S h a b a b^{30}$. It is logically impossible for Somaliland to ask blessing from un-effective and failed "parental state" and that is why it obliged to prefer a unilateral declaration of independence.

\subsubsection{Territory}

Somaliland meets the standard provided by the Montevideo Convention as it has its own defined territory. The defined territory of Somaliland dates back to the British colonial rule. It is bordered by the Red Sea and Gulf of Aden to the North, Djibouti to the Northwest, Ethiopia to the West and Punt land to the East $^{31}$. By recognizing this boarder, Ethiopia signed a long-term use agreement of the Port of Barbara with Somaliland ${ }^{32}$. Recently also, "Ethiopia and Somaliland have agreed to exercise maximum effort to establish short and long-term transit cooperation mechanisms" ${ }^{\prime 3}$. This shows that, Somaliland is still effectively managing and using its clear territorial boundary.

\subsubsection{Population}

In-terms of population, Somaliland has a paramagnet and stable population of nearly at 3.5 million, with an average growth rate of $3.1 \%{ }^{34}$. When the state of Somaliland declared its independence, the people called for referendum and gave its support for the statehood. For example, the people's support for sovereignty in a 2001 Constitutional Referendum was significant and a decade latter its initial declaration of independence another referendum showed ninety-seven percent of the population in favor of independence (Marc, 2006). This referendum was an indication of the interest and even active involvement of the Somaliland people towards the movement of an independent Somaliland state.

\subsubsection{Effective and Strong Government}

With regard to effective and strong government structure, Somaliland established a government which heavily relies on community-based leadership and an inclusive of council of elders (Ismail \& Reginald, 1999). The constitution of Somaliland, which is the supreme law of the land, is among those constitution that

\footnotetext{
${ }^{29}$ Somalia: Al-Shabaab-It Will Be a Long War Crisis Group Africa Briefing N99, 26 June 2014. P. 2.

${ }^{30}$ Integrated Regional Information Network (IRIN), 28 May 2014.

${ }^{31}$ Dilemma of the Horn: the West Pushes for Somaliland Recognition, 34 Def. \& Foreign Affairs Strategic Policy 7 (2006).

${ }^{32}$ The Republic of Somaliland, Somaliland: An African Success Story,

http://www.somalilandgov.com/G8Somaliland.pdf (last visited Dec. 17, 2012).

${ }^{33}$ http://hornaffairs.com/en/2014/01/14/ethiopia-and-somaliland-agree-on-importance-of-transit-co operation-mechanisms-jan-ten/ (last visited April 28/2015).

${ }^{34}$ http://unpo.org/members/7916 (last visited September 27, 2016.)
} 
guarantee the existence of clear separation of power among the legislative, executive and judiciary branches of the government (Fred, 2006). It held Presidential election in 14 April 2003 and the election was a landmark in the self-declared, unrecognized republic's process of democratization. The result of the election was closer than the one in which George W. Bush beat Al Gore and the incumbent president, Dahir Rayale Kahin, had won by only 80 votes. Moreover, Somaliland held Parliamentary election in 2005 and Presidential election in 2010. These regular and periodic elections indicate that, there is a government structure that properly operate and function in Somaliland. Relatively, Somaliland's government is stable one compared to Somalia and Punt Land. It is in Somaliland that $A$-Shabab has no place and the government is defending its people from the threat of the Islamist extremist group.

\subsubsection{Insuring Sovereignty and Making Diplomatic Relationship}

Somaliland has also established a strong diplomatic relationship with different countries and signed treaties. Despite Somaliland's unrecognized status, it has entered into informal and formal relationships with number of other states, and has also achieved de facto recognition from a number of other countries around the world. Somaliland has established offices in the USA, Canada, UK, Sweden, France, Norway, Belgium (Brussels) Ethiopia, Djibouti, Ghana, Kenya, South Sudan, South Africa and Yemen, and people have travelled with the Somaliland passport to South Africa, Kenya, Djibouti, Ethiopia, Uganda, UK, Sweden and USA $^{35}$ Ethiopia is the first country that opened its Embassy in Hargeisa and for the first time ever, Ethiopian Airlines has established regular service between Addis Ababa and Hargeisa ${ }^{36}$. Moreover, Somaliland and Ethiopia have strong trade ties and the port at Berbera is the second-most important harbor, after Djibouti, for imports to and exports from landlocked Ethiopia.

\subsection{What Other States Should Do?}

Based on the above facts concerning Somaliland, other countries should recognize Somaliland as an independent state. As it is mentioned above, as long as the issue of recognition is a matter of states discretionary power and out of the scope of law, states recognition or non-recognition of Somaliland has no legal effect against them. If they want, they can recognize Somaliland as an independent state and contribute their part to the settlement of peace and security in the Horn of Africa. The recognition of Somaliland by other states will have its own significance to abort the illusionary plan of "Great Somalia" and to bring sustainable peace and security in the neighboring Djibouti, Kenya and Ethiopia as they are also victims of such illusionary plan.

Though Somaliland formally applied to join the African Union in 2005, its

${ }^{35}$ The Brenthurst Foundation, African Game Changer? The Consequences of Somaliland's International (Non) Recognition-Discussion Paper 2011/05, (Johannesburg: The Brenthurst Foundation, 2011).

${ }^{36}$ David Shinn, "Somaliland: The Little Country That Could," CSIS Africa Notes 9 (2002), http://csis.org/files/media/csis/pubs/anotes_0211.pdf. [last visited May 3, 2015]. 
application is still pending and did not get response. The African Union should give a pragmatic decision for the membership of Somaliland as its decision is important to bring a long lasting peace in Somaliland and the Horn of Africa.

\section{Concluding Remarks}

Somaliland has declared its independence twenty five years ago. Though it has declared its independence, there is no clear recognition of this by any member states of the United Nation. The question of whether Somaliland should be recognized as an independent state is slowed down only by the blind observance of the international community to the nation-state system's inviolability of borders. The state of Somaliland has fulfilled the requirement of both self-determination and the right to be recognized as an independent state. Somaliland has fulfilled the standards and requirements of the Montevideo Convention. What is left is only the discretionary power of the international community to approve its legal personality and admitting it as a member of the United Nation. What Somaliland lacks is formal recognition of its statehood by other states, a simple act which would enable it to take its place on the world stage and provide a creditable example for other states faced with internal conflict and disorder. The writer of this article boldly argues that, the international community should fulfill its moral obligation of bringing sustainable peace and security in the Horn of Africa by blessing the independence of Somaliland.

\section{Conflicts of Interest}

The author declares no conflicts of interest regarding the publication of this paper.

\section{References}

Alison, K. E. (2007). When Is a State a State? The Case for Recognition of Somaliland, 30 B.C. Int'l \& Comp. L. Rev. 211.

Anthony, J., \& Carroll, B. R. (1993). The Case For The Independent Statehood of Somaliland. AM. U.J. INT'L L. \& POL'Y.

Clarke, W. S., \& Gosende, R. (2003). Somalia: Can a Collapsed State Reconstitute Itself? In R. I. Rotberg (Ed.), State Failure and State Weakness in a Time of Terror. Washington: Brookings Institute Press.

Fred, O. (2006). Breakaway State Has Achieved Peace, Stability, Democracy, East African (Kenya). 28 Feb.

Henry, J. S., \& Philip, A. (2000). International Human Rights in Context. New York: Oxford University Press.

Ian, B. (1979). Principles of Public International Law 287 (3d edi).

Integrated Regional Information Network (IRIN), 28 May 2014.

International Covenant on Civil and Political Rights (ICCPR), 1966.

Ismail, I. A., \& Reginald, H. G. (1999). The Heritage of War and State Collapse in Somalia and Somaliland: Local-Level Effects, External Interventions and Reconstruction, 20 Third World Q. 113, 113.

Jean, P. S. (1948). Anti-Semite and Jew: An Exploration of the Etiology of Hate. New 
York: Schocken Books.

Kelsey, F. (1925). Hugo Grotius on the Law of War and Peace, translation (Carnegie Edition).

Lambert, J. (1995). Betrayed Trust: Africans and the State in Colonial Natal. Pietermaritzburg: University of natal Press.

Lars, V. (2000). Northern Europe: Languages as Prime Markers of Ethnic and National Identity. In S. Barbour et al. (Eds.), Oxford: Oxford University Press.

Lauterpachet, H. (1947). Recognition in International Law, Grotius Classic Reprint Series. Paperback, December 6, 2012.

Malcolm, N. S. (1986). Title to Territory in Africa; International Legal Issues. Oxford: Oxford University Press.

Marc, L. (2006). The Signs Say Somaliland, But the World Says Somalia. N.Y.: Times, June 5.

Markus, H. (2006). Political Identity, Emerging State Structures and Conflict in Northern Somalia. Journal of Modern African Studies, 44.

McDowell, E. C. (1977). Contemporary Practice of the United States Relating to International Law. AM. J. INT'L L., 71, 337.

Nanda, P. (1981). Self Determination Under International Law: Validity of Claims to Secede. CASE W. RES. J. INT'L L., 13, 257.

Paolo, C. (1969). The Somali Republic: An Experiment in Legal Integration. London: Frank Cass.

Peter, R. (2011). The Right to Secede Under International Law: The Case of Somaliland. Journal of International Service.

United Nation Charter (UN), 1945.

United States Department of State Press Relations Office Notice, Nov. 1, 1976, Quoted in Eleanor C.

US Department of State Dispatch, 1990 Human Rights Report: Somalia (Feb. 1, 1991) (Describing the Human Rights Atrocities in Somalia).

Vienna Convention on the Law of Treaties (VCLT), 1969. 